\title{
Seeing Development as Security: Constructing Top-Down Authority and Inequitable Access in Jharkhand
}

Siddharth Sareen

\section{(2) OpenEdition \\ Journals}

Electronic version

URL: http://journals.openedition.org/samaj/4146

DOI: $10.4000 /$ samaj.4146

ISSN: 1960-6060

Publisher

Association pour la recherche sur l'Asie du Sud (ARAS)

\section{Electronic reference}

Siddharth Sareen, « Seeing Development as Security: Constructing Top-Down Authority and Inequitable Access in Jharkhand », South Asia Multidisciplinary Academic Journal [Online], 13 | 2016, Online since 18 April 2016, connection on 24 April 2019. URL : http://journals.openedition.org/ samaj/4146 ; DOI : 10.4000/samaj.4146

This text was automatically generated on 24 April 2019

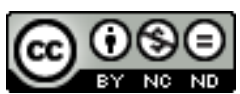

This work is licensed under a Creative Commons Attribution-NonCommercial-NoDerivatives 4.0 International License. 


\title{
Seeing Development as Security: Constructing Top-Down Authority and Inequitable Access in Jharkhand
}

\author{
Siddharth Sareen
}

The author wishes to express gratitude to Iben Nathan, Christian Lund, Jens Lund, Mattias Rasmussen, Patrik Oskarsson, Celie Manuel, Aashish Gupta, participants at the Ghent summer school on 'Governance at the edge of the state' in September 2014, participants at the Danish Institute of International Studies' seminar on Global Political Ethnography in November 2014, and the editors for helpful comments. Generous funding from the Erasmus Mundus joint doctoral programme on Forest and Nature for Society and the University of Copenhagen made this study possible.

'Perhaps to some extent, and at least for some time, in order to promote the idea of itself, it is in the interest of the new Jharkhand state to have a competing notion of an enemy state within' (Shah

2006: 311).

'[...] there is no appreciation for adivasi lifestyles or any attempt to build upon existing strengths, and tired versions of modernization theory continue to be espoused by India's ruling politicians' (Sundar 2012: 163).

1 Governments try to determine resource allocation. In state-building contexts, the extent to which they exercise control is both indicative of their authority and critical for determining distributional outcomes. In India's recently-formed federal state of Jharkhand, the authorisation of access to natural resources and schemes through governmental development interventions presents the following conundrum: How do policies designed to empower marginalised groups and informed by concerns of 
democratic decentralisation get implemented in ways that enable the top-down authorisation of inequitable access through such interventions?

2 Jharkhand was created out of resource-rich southern Bihar in central eastern India in 2000. Complex decades-old political movements demanding its statehood gave way to the challenge of state-building (Shah 2010, Tillin 2011). Having been part of India's attempt at democratic decentralisation since the 1990s, Jharkhand's people in principle became empowered to implement government schemes and authorise access to natural resources in democratic, equitable ways (World Bank 2003).

3 Yet, despite its natural resource wealth, Jharkhand today remains an under-developed region, politically unstable and with historically inept governance (Shah 2010, Prakash 2011). In the 15 years since its formation, it has had ten different governments and three instances of President's Rule. ${ }^{1}$ It is also at the heart of an enduring insurgency led by Maoist groups, with a government counter-offensive (World Bank 2007). In recent years, academic work has frequently cited former Prime Minister Manmohan Singh's statement portraying the Maoist movement as India's biggest internal security threat (Levien 2013a: 367, Chandra 2014: 414).

4 Jharkhand's West Singhbhum, my study district, boasts India's largest iron ore deposits and shorea robusta (sal tree) forest, the $800 \mathrm{~km}^{2}$ Saranda. Comprising a significant minority indigenous population of forest-dwellers, it is populated predominantly by the Ho. The Indian Constitution recognises the $\mathrm{Ho}$ as a Scheduled Tribe, thus according them strong rights over resources and the right to determine local development (GoJ 2006). ${ }^{2}$ Such positive discrimination tries to provide disadvantaged groups sufficient voice to influence processes that affect them (Fraser 2001). But thematic literature shows that populations inhabiting resource-rich areas are nonetheless frequently marginalised (Peluso \& Watts 2001). Studies in Jharkhand show that governmental interventions authorising access to schemes and natural resources have been top-down rather than democratically-driven (Lahiri-Dutt et al. 2012, Sundar 2009, Shah 2010).

5 Thus, the central and state governments attempt to simultaneously promote economic growth through mining, battle the threat of Maoist insurgency, and build a stable, developed state. Local-level institutions manoeuvre through the resultant top-down governmental development interventions; i.e., Ho's customary authorities and nascent decentralised institutions try to exercise their constitutional rights to access resources and determine the nature of development (Jewitt 2008). Hence, authority over and access to resources are fluid and contested in politically-volatile West Singhbhum. Particular governmental actions can impact and transform them both locally.

6 India's central government has made a point of claiming it wants development for West Singhbhum's inhabitants. This is one of 60 districts across India which were funded 55 crore rupees (nine million dollars) each during 2010-12 through an 'Integrated Action Plan for Selected Tribal and Backward Districts'. This anti-insurgency, pro-development intervention has since been extended to 88 districts until 2017 in the form of 'Additional Central Assistance for Left Wing Extremism Affected Districts'. In addition, Saranda forest division within West Singhbhum was earmarked in 2011 for a Saranda Action Plan (SAP). This two-year, 250 crore rupee (41 million dollar) intervention sought to deliver a package of development and security in this forest region (MoRD 2011). Through this 'high modern' or 'hegemonic project' (Scott 1999), the government wanted to 'cleanse' Saranda of Maoists. SAP envisaged increasing military presence and bringing 
development to the forest's Ho inhabitants, to make or keep them pro-government instead of siding with insurgent groups.

7 This article takes this elision of development and security by the government as its point of departure, adding to recent literature that links the state, development and dispossession in India (Baka 2013, Banerjee-Guha 2013, Oskarsson 2015). The Indian Constitution accords Ho communities the authority to determine the nature of development and resource access as the region's inhabitants (GoI 1992, 1996). Typically, those with power try and influence how resource access is authorised through various means (Ribot \& Peluso 2003), which in this case would necessarily mean co-opting the Ho's right to determine and benefit from regional development. Governmental development interventions play a crucial part in influencing the balance of outcomes between these two extremes. Recent regional literature roundly criticises these, arguing that 'in renewing state legitimacy against internal dissent, development goals are made to coincide with traditional security concerns for state survival and stability' (Basu 2011: 373).

8 In what follows I demonstrate how the government, seeing development as security, enables interventions that promote top-down authority, inequitable resource access and dispossession. I argue that the government adopts a prescriptive rather than democratic approach to development, using security concerns to justify impositions that inequitably benefit powerful actors and disenfranchise already marginalised groups. As Gardner and Gerharz note in this volume, whether such governmental interventions are theoretically formulated as explicit elements in an 'Ideological State Apparatus', pace Althusser (1971), or as unintended consequences of a less conscious discourse that nonetheless favours the powerful, studying them shows the practices characteristic of 'regimes of dispossession' (Levien 2013b), and explicates their role in constructing a development paradigm. I explore this in detail by examining the role of several cases of interventions in constructing local-level access to and authority over resources.

9 To do so, I use a framework comprising six practices devised by Li (2007) to unpack community forest management, as an analytical strategy to understand the assemblage of governmental development interventions in Jharkhand. Through this analytical lens, I demonstrate ways in which these interventions enable top-down authority and inequitable access to resources despite legislation against precisely these outcomes. This contributes to an emerging literature on authority and access that currently lacks empirical detail from South Asia (Ribot 2011, Ribot \& Peluso 2003, Sikor \& Lund 2009, Stacey 2015). Matching Gardner and Gerharz's focus in this volume on the use of 'security' and 'development' discourses to justify appropriation and mask dispossession, I show how these occur in both the extreme case of SAP and in ordinary cases of other interventions within the district. Thus, rather than the effects of resource appropriation, my concern is to engage with processes whereby governments, and indirectly corporations, mask dispossession while simultaneously enacting it.

10 Towards this, my article presents a mixed-methods study of two of West Singhbhum's four forest divisions-Saranda (primarily using secondary research) and adjoining Sadar Chaibasa (mainly using primary research). Saranda presents, as described, a case of 'extreme' interventions, particularly the SAP. Difficult to access in terms of safety and permission for field research, it nevertheless comprises communities that, in terms of authority over and access to resources, are comparable to those in forest villages in the adjoining, more 'ordinary' Sadar Chaibasa forest division. Here it was possible to safely 
conduct detailed empirical research in Ho village communities socioeconomically and culturally similar to those in Saranda, maintaining the same focus and studying relatively more everyday forms of governmental development interventions. Showing how interventions construct authority and access in both forest divisions, I argue that this is supported by the elision of development and security in government programmes and discourse.

11 The remainder of the article comprises five sections. I summarise the data collection methods before delving into some background information on the actors and institutions relevant to the authorisation of access in both the forest divisions studied, based on regional literature complemented by field observations. Next, the choice of analytical framework is explained, defining and theoretically locating the main concepts of access and authority in relation to it. Thereafter comes the findings and analysis section, which details how governmental development interventions are assembled and reflects on the six practices that hold them together, using multiple cases to explain the impact of these interventions on local-level access and authority. To conclude, I address the main research question, i.e., how eliding development with security constructs authority and access locally.

\section{Data collection}

This article is based on six months of empirical research carried out between January 2013 and January 2015 in Sadar Chaibasa forest division. Fieldwork was conducted both in Ho using a Ho-Hindi interpreter and in Hindi by the author, who also transcribed all field material into English. Interviews took place across 20 villages, with an emphasis on five villages in which relations of trust were built up over four phases of field research. The study comprises 107 semi-structured interviews and six focus-group discussions focussing on authority over and access to resources. It includes 49 key informant interviews and 48 structured interviews focussing on property, authority and access to government schemes and local livelihoods. A study of thematic grey literature and 150 newspaper and magazine articles (via national media websites) specifically about SAP during the 2011-2014 period, undertaken in addition to two field visits to the Saranda forest division, covering a dozen of the 56 villages included under SAP, complements this material.

\section{Background: Institutions authorising actors' access in West Singhbhum}

13 West Singhbhum district is a Fifth Schedule area inhabited by constitutionally-recognised Scheduled Tribes, primarily the Ho people. Through the $73^{\text {rd }}$ Constitutional Amendment, the Panchayat (Extension of Scheduled Areas) Act (PESA), and the Scheduled Tribes and Other Traditional Forest Dwellers (Recognition of Forest Rights) Act (FRA), India's constitution and community-oriented legislation give the Ho authority over resource access and local development in accordance with their tradition (GoI 1992, 1996, 2007). At the local level, the government recognises two parallel institutions. One is mandated by the government as a legacy of a legislatively distinctive part of the district that includes my study region, the colonial-era Kolhan Government Estate. A government officer called 
the Kolhan Superintendent is supposed to assist customary village chieftains who preside over matters of local development and resource access in this part of West Singhbhum (Rath 2006). Besides this system of customary chieftains or munda-manki, there is a local democratic institution called the village assembly, set up as an outcome of the democratic decentralisation process attempted nationwide from 1992 onward (Sundar 2005). The village assembly is by definition a participatory body at the community level. But the Jharkhand government's line agencies-such as Panchayati Raj (decentralised governance), Tribal Affairs, and Land Revenue-who are in charge of implementing the mentioned constitutional acts, lack the requisite strong ground presence to enforce and support the benefits of such recognition in remote forest villages (ELDF 2012).

The Forest Department is a line agency actually present on the ground, but lacking sufficient manpower and experienced staff (GoJ 2013a), and has a history of conflict with communities (Areeparampil 1992). The Forest Department de facto manages a great deal of government-owned forest, large parts of which are categorised as protected or reserved forest in the study region, which consists of two of West Singhbhum's four forest divisions. Historically, it benefitted from commercial forestry revenues accruing largely from contracting out forest compartments to private companies on fixed short-term leases, and in recent years has done little to fulfil its function of managing these forests sustainably (Kumar 2002). Moreover, in Saranda forest division there are over 60 existing and pending mining concessions leased out to large mining companies for 20-year periods (Shah Commission 2013). Not only are the Forest Department and mining companies functioning at odds with legal safeguards provided to the Ho, there is also a lack of awareness and implementation of safeguards by both forest inhabitants and government officials (Padel \& Das 2010).

Another relevant line agency is the District Rural Development Agency, which provides livelihood-generating schemes meant to lead to resource access for villagers in two ways: directly, by creating durable assets like wells and ponds and undertaking forestation and landscaping activities at the village level, and indirectly, through income accruing to villagers, which helps them to purchase resources that would otherwise be unavailable. It is known that, typically, local elites work as contractors and pocket some of the money from such schemes, ${ }^{3}$ and Maoist groups at times demand a share as well (Shah 2006).

\section{Theory and analytical framework}

The two main concepts this article engages with are access and authority. I define access as 'the ability to derive benefits from things' (Ribot \& Peluso 2003: 153), where 'things' for this study specifically refers to mineral and forest resources, land, and development schemes. Access is broader than the term property, including benefits that accrue to actors not only through legal rights but also via structural and relational mechanisms. These latter access mechanisms have to do with exercising power. Power thus exercised, when recognised by an institution as legitimate, constitutes authorised access. In this regard, authority refers to 'the capacity of politico-legal institutions to define and enforce collectively binding decisions on social actors', combining Lund (2011: 887) and Sikor and Lund (2009: 1). Since authorising access determines configurations of distribution of benefits, it is a political act (Freudenburg 2005). Authorisation recursively impacts various actors' access in myriad ways. In a resource-conflict, state-building context, institutional authority is shaped by actors at multiple sites. Authorising access in turn 
authorises the authoriser; hence access and authority are co-produced (Sikor \& Lund 2009, Ribot 2011).

This definition of authority is based on the understanding that the state has a 'double nature as an idea and an apparatus' (Abrams 1988, Lund 2008: 181). I understand 'apparatus' after Foucault (1980) as constituted of heterogeneous discourses, institutions, regulations and laws, i.e., of 'positivities' that are enforced or obligatory (Foucault 1972), and study authority through investigating how some of these positivities 'act within the relations, mechanisms and 'plays' of power' (Agamben 2009: 6) that determine actors' access to resources.

politico-lega institutions exercising authority at the local level. My choice of cases (of governmental development interventions) necessitates foregrounding the role of the government, which comprises multiple line agencies. It includes India's central government and Jharkhand's state government. The former is established strongly enough that the idea of authority remains linked with the government. But the latter has been fragile, even dyfunctional in some ways (Tillin 2011). Since some legislative decisions and most policy execution is up to the state government, there are gaps in authority and contestation over determining resource access, and thereby the nature of development, at sites of resource struggle (Bedi 2015, Sundar 2009, Sud 2014).

If governmental actions do successfully authorise access, the way they do so builds a certain kind of state. They can establish or nurture local-level authority and democratic decision-making in keeping with progressive, equity-oriented policies, or they can favour some actors over others by authorising access in a predetermined, top-down manner. Studying governmental interventions thus enables an understanding of how access and authority are constructed (Oskarsson \& Nielsen 2014). It is here that a process-based analytical approach can capture the implications that state-building has for how resources are allocated and to whom.

The act of governmental intervention, or more broadly of government, which I consider several cases of in this article, has been richly theorised. Foucault (1980) addresses the 'conduct of conduct', or how disparate elements are assembled into a governable configuration. This is an apt framing upon which to base an approach to untangling interventions. Building on a broadly Foucauldian understanding of government, Li (2007) proposes an analytical framework through which to understand this act of bringing together, of assemblage. Her framework situates individual agency and employs six generic practices to unpack how an assemblage works. As Legg (2011: 131) comments, this 'explicitly blurs any distinction between assemblage and apparatus, [...] turning the former into an act of labour and governance'. While at times using her own long-term ethnographic work in Indonesia, Li draws widely on other scholars of community forest management to explicate these practices. She explains the latter as a 30-year-old assemblage, arguing that six practices hold together the diverse elements comprising it. I use the generic practices she elaborates as an analytic strategy to approach the assemblage of governmental development interventions examined here, linking interpretations of my findings to these more abstract practices.

21 By 'practices of assemblage', Li (2007: 263) means 'the on-going labour of bringing disparate elements together and forging connections between them'. She argues that this happens through these six practices: forging alignments, rendering technical, authorising 
knowledge, managing failures and contradictions, anti-politics, and re-assembling. Li (2007: 263) uses these to study 'the gap between the will to govern and the refractory processes that make government so difficult.' In this article I employ these practices to understand that which animates the gap between the discourse of democratic authority and resource access and the actual practice of top-down authority and resource access, namely governmental interventions based on seeing development as security in Jharkhand. This analytical approach enables an emphasis on processes rather than effects, with each practice helping to bring out different aspects of how resource access and authority are constructed.

\section{The practices of authorising resource access through governmental development interventions}

In this section, I take up various cases of governmental development interventions, approaching each of them using one of the six practices of assemblage in order to analyse how the intervention impacts authority over and access to resources. Proceeding sequentially through the practices in six sub-sections, I begin each sub-section by summarising the case or cases it is concerned with and the outcome of my analysis. These summaries are then elaborated by using the specified practices to analyse how these interventions affect authority over and access to resources. To conclude each sub-section, I refer to Li's (2007) definition of the practice, reflecting on how the analysis of my material relates to this definition.

\section{Forging alignments}

This practice helps explain how governmental interventions transfer land from indigenous inhabitants and conservation purposes to mining companies in Saranda by forging alignments between national interest, biodiversity conservation and mineral extraction. Aligning land acquisition with national interest on the one hand, and aligning environmental clearance processes with industry-sponsored environmental plans on the other, authorises access to land for mining. Simultaneously, such alignment vests authority in a national-level pro-industrialisation body, detracting from the authority of community-level democratic institutions.

Government policy is contradictory in terms of authorising access to land and resources in Saranda. On the one hand, national-level acts safeguard the Ho's resource access and authority as a Scheduled Tribe (GoI 1992, 1996). Moreover, a colonial-era tenancy act renders their privately-owned and community land untransferable to non-tribal people (Sen 2011). But the earlier 'Land Acquisition Act, 1894' and its recently legislated replacement, the 'Right to Fair Compensation and Transparency in Land Acquisition, Rehabilitation and Resettlement Act, 2013' (LARR Act), enable land to be taken away for mining, prioritising this as a public purpose despite the Ho's constitutional rights. The Forest Department continues to control large chunks of forest, authorising its own access in contravention of PESA and FRA (cf. 'Background' section in this paper). Here I show how these contradictions are overcome by the practice of aligning and converging various interests. 

configuring access is apparent in how mining concessions are authorised in Saranda. Granting mining concessions requires two stages of environmental clearances through a process involving multiple authorities. These include the national-level Forest Advisory Council and Ministry of the Environment and Forests (MoEF), state and sub-state Forest Department officials, ${ }^{4}$ community-level village assemblies with the constitutional right to self-determine their development, and the Cabinet Committee on Investment (CCI, formed 2012). Granting concessions also requires taking over land from private or community ownership and/or from conservation purposes of the Forest Department. For this the government has used land acquisition laws to claim land for a 'public' purpose. This banks on the government's 'eminent domain' over territory in the 'national interest' (Sharan 2005), with land subsequently often transferred to mining companies.

art from aligning the transfer of indigenous land to mining companies with the discourse of development in the national interest, the government also has to sidestep its own conservation rules. Development in the Saranda forest requires the MoEF's approval as it is a core elephant reserve area. Applications for mining licenses and concessions often remain stuck at this point, pending second-level clearance. But in recent years, quick shuffles in the ministerial position and the CCI's formation have effectively circumvented this obstacle for mining companies. Two MoEF ministers with two-year tenures each (2009-11 and 2011-13) gave way to an MoEF minister (2013-14) who already held the petroleum and natural gas ministry portfolio, and who cleared a record number of applications (70 projects in 20 days) prior to India's 2014 national election. ${ }^{5} \mathrm{He}$ has been succeeded by the current minister, whose actions within a 'pro-growth' industrychampioned new government have been heavily criticised in the national media (e.g. Sethi 2015, Gupta 2015), while environmental clearances continue flowing rapidly.

All projects affecting the environment have not, of course, suddenly become more benign. A recent government report highlights severe irregularities in granted environmental clearances and the prevalence of widespread illegal mining (Shah Commission 2013). But approval processes have failed to relate to environmental implications, instead making choices aligned with the government's and companies' political and commercial ends respectively. For instance, a court ruling required an Integrated Wildlife Management Plan (IWMP) to be produced for the Saranda forest before any clearances could be issued, due to the conservation-linked potential of the forest as a core elephant habitat and Asia's largest sal forest. Before the IWMP was finally approved in 2013, the recently-founded CCI within the government lobbied to have the IWMP delinked from the clearance grant. Such a request undermines the entire logic of environmental regulations, working with a predetermined idea that all environmental clearances should be given. The eventual IWMP's acknowledgements section thanks the Steel Authority of India Limited (SAIL) for sponsoring it, expressing gratitude to Tata Mines and others (GoJ 2013b). Despite the clear conflict of interest, this became the basis for allowing mining companies to lease the land. Its recommendations align environmental sustainability with mining-driven development: 'It is important to ensure the conservation of the rich biodiversity along with the extraction of minerals for prosperity' (GoJ 2013b: 200).

Li (2007: 265) defines forging alignments as 'the work of linking together the objectives of the various parties to an assemblage, both those who aspire to govern conduct and those whose conduct is to be conducted'. This sub-section has shown how interventions align 
national interest with industrial interests to acquire land for and grant environmental clearances to mining companies.

\section{Rendering technical}

This practice illustrates how interventions reduce complex political issues in Saranda to technical requirements for development and security, while actually helping achieve infrastructural and security prerequisites for mining companies. This technicisation obscures the contradictions (Rose 1999) over authority and resource access that are at the heart of struggles for different kinds of development in Saranda. Similarly, in Sadar Chaibasa, rendering livelihood-generating schemes technical makes it difficult for inhabitants to actually access the benefits intended for them, and favours decisionmaking by higher-level institutions over local democratic authorisation of development.

While access to land was authorised in the form of 20-year mining leases, the SAP was the vehicle for rendering the requirements of development and security in Saranda technical. It purported to aim for Ho community development, primarily through pre-existing but unimplemented welfare schemes in Saranda's 56 villages, and for security against Maoist insurgent groups in the region. Its short-term (half-year) goals included distributing solar lanterns, bicycles and transistors to every household, ensuring all qualifying households became registered recipients of existing welfare schemes and implementing the Mahatma Gandhi National Rural Employment Guarantee Scheme (known as NREGA) to support local livelihoods. It also envisioned providing employment-linked skill training to young villagers, conducting health camps, installing handpumps to supply drinking water, and undertaking road construction and watershed development under existing schemes. A mining company sponsored the handpumps, which were meant-but failed-to fix the problem of high iron content in the water that large-scale active mining in the Saranda forest had exacerbated by colouring its rivers red (Ray 2012, Pandit et al. 2014). The entitlements SAP offered were already part of existing nationwide government programmes, though some guidelines were relaxed to enable prompt, inclusive coverage. ${ }^{6}$ Less specific medium-term (two year) components focussed on enabling local livelihoods, starting residential village schools, and constructing 11 'integrated development centres' for welfare service delivery. In parallel, the Indian government planned to establish its military presence in Saranda.

31 An analysis of the published SAP (MoRD 2011) reveals a simplistic approach, one which tries to achieve 'development' and 'security' through the above technical measures. It aims to render villagers-antagonised through decades of government-community conflict and indifference (Areeparampil 1992)-pro-government by providing basic entitlements, while undertaking militarisation and road-building to consolidate territorial control recently gained through military operations against Maoist groups in the Saranda forest. ${ }^{7}$ But road-building does not appear to be for community development alone. Building heavy-duty motorable roads has also opened up Saranda for multi-tonne mining trucks. In parallel, the government has set up paramilitary camps at strategic locations throughout the forest, claiming that this is to ensure secure implementation of the development schemes.

The SAP has thus directed attention away from the contradictory legislation authorising resource access, towards issues of security and development. It has highlighted that these latter two are conjoined and require a combined strategy, assuming rather than publicly 
examining the feasibility and merits of this task. Media coverage relating to SAP has frequently mentioned 'flushing out Maoists' and mining concessions. Thus, rather than prioritising the Ho's constitutionally-safeguarded continued resource access in Saranda, the SAP has presented development and security in a technical manner that has established infrastructural and security prerequisites for leasing land to mining companies. On the one hand, the Indian government has explicitly claimed that its purpose in securing and developing the iron-rich Saranda forest is not to open it up to large mining companies (Vishnoi 2013). On the other hand, it gave out a spate of land concessions and iron-ore mining licenses to several corporate houses in precisely this region shortly after SAP commenced. ${ }^{8}$

Interventions in Sadar Chaibasa are also based on a governmental understanding of its issues as technical problems. The District Rural Development Agency implements development schemes under the NREGA, paying a daily minimum wage for up to 100 days of work per household per year on manual labour-driven infrastructural projects within villages. Physical inspections in 20 villages indicate that these projects most often fail to result in durable assets, with interviewed villagers stating that 'even if a pond is sanctioned it doesn't get dug properly and there is no water in it' and that 'There are no durable assets made but people get employment. ${ }^{10}$ Projects serve primarily as a local offseason income source for villagers, instead of those villagers migrating or engaging in illegal wood sale. But rules meant to ensure accountability and transparency hold back even this scheme's performance due to other factors being insufficiently addressed.

For instance, district-level officials reported that instituting electronic payments into individual accounts is a technical requirement of NREGA to prevent project contractors siphoning off labour wage funds. But the banking infrastructure is poor and awareness on how to use bank accounts is low. This has resulted in delayed payments, making many villagers lose interest in the scheme. It has also cut off many villagers' access because they have been unable to open bank accounts and specify bank account numbers in order to obtain a job card that the scheme requires. Moreover, project contractors can exploit some villagers' lack of awareness of the banking system and appropriate profits in their name anyway. ${ }^{11}$ For instance, interviewed villagers stated that 'assets made do not work because the contractor eats up the money ${ }^{12}$ and that the "mukhiya [local councillor] earns out of it, taking most of the money for personal use', ${ }^{13}$ with a contractor boasting about extracting money: 'a tender gives 3.5 lakh rupees for each $\mathrm{km}$ of road, I spend 1.5 lakh rupees and pocket the rest'. ${ }^{14}$ Special central-government schemes, funding similar infrastructural projects as a way to render villagers pro-government, are exploited despite similar technical safeguards. On the one hand, contractors illicitly increase their profit margins. On the other, the very Maoist insurgent groups these schemes are targeted against ironically demand protection money from project contractors to let the projects proceed.

Not only are these technical solutions unable to achieve their intended outcomes due to complex factors they do not apprehend, they also undermine PESA's constitutional mandate to let village assemblies determine development. While they go through the motions of getting village assemblies' formal approval, projects are actually selected in a top-down manner and influential men become scheme contractors and gain benefits repeatedly. ${ }^{15} \mathrm{~A}$ UNDP-funded project improving NREGA implementation tried to target this by training and involving some villagers near the tail-end of my fieldwork. Even so, specifying technical requirements such as village-assembly approval does not address 
substantive problems like the fact that power and resources remain concentrated in the rural development line agency at higher levels, and are allocated inefficiently without downward accountability, a substantive basis, or democratic decision-making. Interviewed street-level bureaucrats complained that there were insufficient funds and resources to ensure meaningful implementation according to technical requirements, and that their own salaries were six months delayed.

Li (2007: 265) defines the act of rendering technical as 'extracting from the messiness of the social world, with all the processes that run through it, a set of relations that can be formulated as a diagram in which problem (a) plus intervention (b) will produce (c), a beneficial result.' This sub-section has shown how interventions institute technical requirements, enabling a top-down security agenda to drive resource allocation, and keeping local demands from determining the nature of development.

\section{Authorising knowledge}

37 This practice illustrates how interventions shape the dominant discourse around development and security, selectively authorising knowledge that contributes to this while containing critique. In Saranda, this takes place through government officials' individual actions and mobilising a positive image of SAP as the requisite response to an urgent need. While inhabitants in Sadar Chaibasa are critical of similar militarisation around them, the government does not concede mistakes or entertain the possibility of intervening differently. This helps bring about and maintain governmental control over territory and, consequently, top-down authority over resource access.

Saranda forest division's SAP was made the focus of attention by the government, highlighting anti-insurgency operations in the region alongside welfare measures for local marginalised groups. It was based on a trip made by bureaucrats and international development agency officials in consultation with the district administration, without the participation of village assemblies or local representatives mandated by India's constitution (GoI 1992, 1996). Thus, SAP's claims of bringing the Saranda's Ho people 'development' lacked nuance, contextualisation, and even legality. But with the backing of the then-Union Minister for Rural Development, it shaped the dominant discourse around Saranda and West Singhbhum district. Despite mixed media attention, the government's official line has been unwaveringly positive. A letter to the Minister based on a joint fact-finding mission by the Jharkhand Human Rights Movement and National Human Rights Commission criticised SAP on two main counts (JHRM 2012), but prompted no government action to address these charges:

- It accused SAP of being a cover-up for government atrocities against indigenes during an August 2011 anti-insurgency paramilitary Operation Anaconda, involving a month-long military occupation of several villages' land.

- It pointed out that most money being spent in Saranda was being used to make heavy-duty roads motorable by loaded trucks, despite villagers only being given bicycles, indicating a state-industry nexus in favour of mining disguised as building security through pro-villager rural development.

Seen as the champion of SAP, the then-Minister's role is worth considering for its sheer performativity in selectively authorising knowledge. He visited frequently, calling Saranda a 'liberated zone' from Maoist influence, flying the flag on a national day and taking a personal interest in monitoring SAP's progress. Newspapers took note but also 
pointed out villagers' daring negative comments concerning how SAP had not delivered effectively after two years. In fact, SAP featured 11 tarred roads under the 'Pradhan Mantri Gram Sadak Yojana' rural roads project. ${ }^{16}$ While villagers were being given bicycles, the larger development of an extensive network of heavy-duty tarred roads throughout the Saranda forest was left unexplained, save as means to improve governmental communication and increase security. A journalistic exchange in a national newspaper with the then-Minister failed to result in a transparent explanation of why the only really operational aspect of SAP seven months into implementation was the setting up of 21 police camps, purportedly to ensure the progress of development schemes which there was little evidence of (Sethi 2012a, 2012b, Ramesh 2012). The then-Minister's response failed to recognise or address any of the substantive issues put forward, leaving the research and journalistic community engaged in these questions in little doubt that the infrastructure development was to open up the region for mining even beyond existing leases.

Despite consistent coverage by journalists,${ }^{17}$ sources of in-depth knowledge about SAP's implementation remained scarce. A dedicated government-run SAP website (saranda.nic.in) gave sporadic and dated information, and the 'Special Nodal officer' had not been given any special powers or authorisation. Currently Sadar Chaibasa's Divisional Forest Officer (DFO) and ex-DFO of Saranda, he confirmed to me that no 41-million-dollar SAP budget had been set aside. It was all supposed to come from the 'convergence' of various government schemes towards similar ends for integrated development. Thus, what made SAP special was not its substantive content but the discourse mobilised around it: the knowledge authorised about what it was supposed to be rather than what it actually was. Aspects at odds with seeing development as security were simply erased from the official picture.

41 This selective authorisation of knowledge is part of a larger narrative. In 2008-2009, a national report omitted an officially-commissioned chapter on governance in tribal districts (Kirpal 2010). This chapter highlights progressive legislation like PESA, that enables adivasis (tribal people in India) to self-govern, revealing 'a damaging mix of misgovernance, alienation and violent insurgency' by the government against them (Dandekar \& Choudhury 2010: 16). In my Sadar Chaibasa study villages, I commonly encountered tales and even village assembly minutes detailing abuse of authority by government paramilitary forces, ranging from harassing Ho women to robbing village households of grain, fruits, poultry and other valuables, all while claiming to protect them or search for insurgents, confident that the government would not bother bringing its soldiers to book. Most villagers, when interviewed and during informal exchanges, said the Maoists didn't harm them, occasionally visiting overnight in a group, asking for a meal and enquiring about whether the government was helping them. Government schemes were reported as being occasionally helpful, but hard to access and often dysfunctional, and villagers saw themselves as largely unaffected by both entities. ${ }^{18}$ They said Maoists were a threat to the government and took protection money from scheme contractors, but treated villagers well; the latter had nothing the Maoists would want to take from them anyway.

This narrative is entirely missing from media coverage or the government narrative about bringing security to the district. Resistance to SAP-like interventions has been visible in the form of protests against the proposed setting up of paramilitary camps at multiple sites. Yet this knowledge has not been authorised. There has been no official 
discussion of the fact that villagers do not necessarily see Maoists as a security threat to them. Even though Maoists disrupt government development schemes by demanding protection money from contractors, paramilitary interventions also have negative effects on villagers for reasons that are neither accepted nor addressed.

Li (2007: 265) defines authorising knowledge as 'specifying the requisite body of knowledge; confirming enabling assumptions; containing critiques.' This sub-section has shown how interventions authorise information that equates development with securitisation to maintain top-down governmental control over resources, ignoring critique directed towards more democratic authorisation of access.

\section{Managing failures and contradictions}

Muddling through requires compromise. This practice is evident in governmental interventions such as forest working plans in Saranda that are written without the intent of implementation. Knowing it lacks the wherewithal to implement plans, the Forest Department nonetheless replicates the form of authority without the substantive content, underscoring its authority over access to the forest's resources. In Sadar Chaibasa, the Forest Department stops supporting a successful village-level democratic institution rather than addressing security threats that crop up there. Where the government's topdown authority over resource access is not adversely affected, it manages failure by deserting interventions without risk of political fallout rather than supporting both development and security.

At the sub-district level, the Forest Department controls most forest land, despite overlapping, unclear legislation, based on long-term institutional history here and elsewhere in India. It is only allowed to design interventions based on ten-year forest working plans. In West Singhbhum's four forest divisions, these plans were delayed, with ad-hoc annual plans serving as interim contingency measures for about five years. The new ten-year plans were finally completed and approved for 2013-2023 in Saranda and Sadar Chaibasa. The Saranda DFO told me they lacked a baseline study and the wherewithal to do one-he estimated it would take two years and significant skilled manpower and expense to develop a meaningful long-term working plan. Instead, rehashed versions of dated old plans with some available current details were put together, with little empirical basis but a technical proforma. Though things were not quite as neat and tidy as one might like, schemes were planned as if they were, just as for SAP.

The same DFO admitted that he and most forest staff had never seen forestry interventions, such as felling series, being implemented during their entire careers, due to a history of conflict since the 1970s between local communities and the Forest Department, which prevented commercial forestry from being conducted in a 'scientific' manner (Areeparampil 1992, Corbridge \& Jewitt 1997). In spite of the staff's lack of training, the new Saranda ten-year plan details various felling series, bolstering the Forest Department's authority. The forest working plan also makes detailed rules about villagers' resource access, despite the department lacking manpower to monitor access and the common knowledge that rules are not implemented. This act of rule-making runs counter to constitutional mandates to devolve power and resources to local communities. The manpower crunch, which the vast supposed expenditure under SAP did not envisage changing, shows that actual implementation of the working plan is not on the 
government's agenda. Rather, making plans is a way of managing contradictions through the display of authority (Nightingale \& Ojha 2013).

47 I did, however, encounter an outstanding success story during my research in Sadar Chaibasa, in a village called Bhatu. ${ }^{19}$ Through its village assembly, Bhatu's inhabitants regulated resource access through forest boundary demarcation, group patrols and levy of fines for breach of rules, and demanded local livelihood-generating schemes from the Forest Department with frequent success during 2012-14. Dozens of villages within a 10$\mathrm{km}$ radius cited Bhatu's village assembly as a remarkable success. However, in late 2014, some of these villages were witness to three incidents in quick succession: a post office robbery, a kidnapping of four mining security officers by insurgents, and the arrest of three Maoists with arms and ammunition from a villager's house. On interviewing the Sadar Chaibasa DFO in January 2015, I found the district administration had advised him to cease visiting Bhatu for his own safety. Consequently, in late 2014, the Forest Department stopped sanctioning work in Bhatu, depriving its village assembly of the governmental support that had been crucial to its becoming a model local selfgovernance institution.

Instead of extending this success and building security through further development and support of Bhatu's self-governance and livelihood-generation efforts, the government opted to withdraw even its rare functional intervention. This was precisely a conjuncture where development and security could have been substantively combined to the benefit of local inhabitants. But the government's response to the security failures in Bhatu was to abandon rather than support both villagers and development. The governmental depiction of Saranda as being qualitatively different in its security challenges than this adjoining division allowed it to neglect its failure here. Thus another way that the government managed failure was to abdicate responsibility if it did not have high-profile political repercussions.

Li (2007: 265) defines managing failures and contradictions as 'presenting failure as the outcome of rectifiable deficiencies; smoothing out contradictions so that they seem superficial rather than fundamental; devising compromises'. This sub-section has shown how interventions help perpetuate undemocratic governmental control over resources and fail to direct efforts to support substantive developmental efforts as long as there is no cost to the government's authority over resource access.

\section{Anti-politics}

50 This practice shows how interventions turn political issues, such as authorising access to resources, into developmental ones in Saranda, by camouflaging land concessions for mining as regional development. Not recognising such acts as political and dealing with them as technical issues (Ferguson 1990, Mitchell 2002) constructs forms of access that support the status quo, limiting deliberative spaces in the process (Cruikshank 1999).

In February 2011, the then-MoEF minister cited 'national interest' while sanctioning public-sector company Steel Authority of India's (SAIL) lease of Chiria, India's largest iron ore deposit, in Saranda forest division, despite national-level Forest Advisory Council recommendations against it. SAIL's existing lease on the Gua iron ore reserves, also within Saranda, lapsed in June 2011. Three months later, the Minister in his new capacity as Minister for Rural Development launched SAP, stating its intent to be 'development' (MoRD 2011). In April 2012, SAIL's Gua mine lease was renewed. The Minister approved 
SAIL's mining leases in the 'national interest', emphasising that this was an exception rather than a precedent for concessions to private companies in Saranda. But his successor at the MoEF pointed out that he had in fact also approved a lease to Usha Martin, a private company. The company used this precedent as the basis to lease out thousands of additional hectares in mining concessions.

Despite guaranteeing that no private-sector company would be given mining leases, the Indian government thus approved multiple leases in this mineral-rich reserved forest to large mining firms. Since the start of this study in 2012, several pending mining leases have been approved, in addition to the 42 that already existed. Widespread illegal mining is being carried out alongside these discrepancies in according mining leases (Shah Commission 2013); yet the government does little to address such problems, while continuing to give out leases citing questionable technical and legal grounds.

Li (2007: 265) defines anti-politics as 'reposing political questions as matters of technique; closing down debate about how and what to govern and the distributive effects of particular arrangements by reference to expertise; encouraging citizens to engage in debate while limiting the agenda'. This sub-section has shown how interventions approached political issues concerning the very nature of development as a matter of 'national interest' to keep sanctioning mining leases in a reserved forest.

\section{Re-assembling}

This practice illustrates how governmental development interventions take on new life, with some components added and others removed. The SAP is deemed a model programme and is planned to be replicated elsewhere (Gupta 2015), promoting how it constructs access through top-down authority by conflating development and security. Recent progressive legislation is co-opted by higher-level authorities in Sadar Chaibasa, keeping villagers from using it for establishing land claims through their local democratic institution, while the Forest Department maintains its historical hold over most forest land.

The official coordinating most activities under SAP's umbrella was the District Planning Officer, who is closely associated with the Deputy Commissioner, the district's top official. Both were positive about SAP when interviewed in 2015, but felt it had succeeded only in very modest terms to bring security to the region, which remained unsafe due to Maoists. They agreed that a lot remained to be done in terms of development. Indeed, a quick comparison with my study villages in Sadar Chaibasa shows a rather different set of selfstated priorities of villagers than SAP addressed: local livelihood provision and improved market linkages for non-wood forest products with support for fair prices, regular access to entitlements such as pensions and labour wage payouts, and better healthcare and education services. ${ }^{20}$

In 2014, SAP was still far from fulfilling even its short-term objectives. However, the district officials I interviewed emphasised skills training and schooling for Saranda youth at centres that required them to move out of their villages. They showed no concern for the Ho being allowed to maintain their way of life or define the terms on which development takes place in the region. Their overall perspective reflected that development is going to happen in this manner anyway, and that it is good for the Ho to have received some benefits and been made aware of decisions (such as mining 
concessions) that would have been taken regardless of their views, even though they are the ones most affected by the decisions.

The Indian government has termed SAP a model for similar interventions in other insurgency-affected (and natural-resource-rich) areas. In August 2012, the Minister credited with conceptualising SAP launched a 400 crore rupee (64 million dollar) Sarju Area Development Action Plan in Jharkhand's Maoist-affected, mineral-rich, forested and indigene-populated Latehar district, modelled on SAP. Even with new central and state governments having replaced the national party that promoted SAP, national media quoted Jharkhand's top officials as planning at least ten interventions modelled after SAP in other districts characterised as resembling Saranda (Gupta 2015). Thus an intervention eliding development with security has become a template for dealing with insurgency and enabling 'development' in the form of large mining concessions to private companies, while distributing some largesse to displaced and affected forest inhabitants. This instantiates the practice of re-assembling.

Another example of re-assembling comes from my field research in Sadar Chaibasa. Despite 'affirmative action'-based constitutional recognition of village assemblies as legitimate democratic self-governance bodies, the government has failed to empower these community-level institutions, resulting in top-down administrative decentralisation without downward accountability. This can at least partly be attributed to the land-rich Forest Department being a stronger line ministry than the line ministry for decentralised self-governance, and the devolution of power and resources still being a bureaucratic, top-down process (Lele et al. 2010). As the district administration has placed little emphasis on awareness-raising, most Ho communities remain largely unaware of the full extent of access and authority vested in them.

This is most evident in the functioning of the FRA. A modest 2,800 land claims have been granted to villagers in the entire district since the progressive act's advent in 2006, according to the District Welfare Officer. This number is very low considering that the FRA empowers village assemblies to authorise such claims, followed by two higher-level government committees. Some decades ago, families from several of my study villages set up a cluster of 30-odd households by clearing the forest in the Ho's traditional style: khuntkatti. ${ }^{21}$ Thrice they have pooled 500, 300 and 150 rupees per household respectively -not a trivial sum across over 30 households-and paid it to officials in various relevant government offices to file a land claim under the FRA, which is supposed to be free. Yet no claim has been filed and their land rights remain unrecognised.

Relevant officials for helping execute the FRA are the District Welfare Officer and Kolhan Superintendent (cf. 'Background' section in this paper). From my interviews and observations, these officials came across at best as indifferent and passing the buck, and at worst as acting in a self-serving manner while assigning blame elsewhere. With no downward accountability, the mentioned households have not succeeded in filing a land claim, let alone receiving a title deed. Despite new laws like FRA, the substantive reality remains the same-getting land registered is a top-down process, with a few claims granted sporadically. ${ }^{22}$ Meanwhile, villagers with a legitimate claim do not have village assemblies empowered to approve their claims and hold higher authorities accountable. The status quo of the Forest Department controlling land and villagers being unable to decide about their own land has been maintained.

61 Li (2007: 265) defines re-assembling as 'grafting on new elements and reworking old ones; deploying existing discourses to new ends; transposing the meanings of key terms'. This 
sub-section has shown how interventions are reinvented in ways that replicate and perpetuate the status quo of top-down authorisation of inequitable resource access, despite attempts at democratisation.

\section{Conclusion}

62 This article began with the conundrum: How do policies designed to empower marginalised groups and informed by concerns of democratic decentralisation, get implemented through governmental development interventions in ways that enable the top-down authorisation of inequitable access in Jharkhand? I have tried, using cases from two forest divisions of West Singhbhum and focussing on many instances of authorising access, to illustrate the practices through which governmental development interventions build an inequitable state in a top-down manner. I have argued that the six practices respectively show how SAP and other interventions have:

i. privileged powerful actors without a substantive legal basis;

ii. opened up the area without serving local needs, and excluded ordinary people without managing to solve targeted problems;

iii. let the powerful decide and contained any critique, without holding the powerful accountable;

iv. authorised access without a scientific basis, and failed to offer continued support to a successful local-level democratic institution;

v. broken governmental promises to privilege access for powerful actors; and

vi. been replicated without taking lessons from substantial failures, and not compelled officials to be responsive to demands.

63 In untangling the practices through which governmental interventions construct inequitable access locally, I have argued that the conflation of development and security (and at times the narrow definition of development based on the governmental prioritisation of security-related concerns) that frames and justifies these interventions enables the mutual constitution of top-down authorisation and inequitable access. This builds an inequitable, undemocratic local-level state. There are doubtless many governmental development interventions besides those I have examined here. My intent has been to present an argument firmly grounded in empirical data, with each practice illustratating not just governmental action in a single instance, but rather representing certain tendencies in terms of how access is authorised and to whose advantage.

64 Whether through forging alignments, rendering matters technical, authorising knowledge, managing failures and contradictions, practicing anti-politics or depoliticisation, or re-assembling themselves, governmental development interventions consistently served to favour de facto top-down authorisation of inequitable access rather than to ensure the democratic authorisation of access. This was not only the case in the 'extreme' case of Saranda forest division, but also in 'ordinary' Sadar Chaibasa. I have argued that this was enabled by the government seeing development as security, which, even though it pertained primarily to Saranda, favoured those with power and resources in both forest divisions, rather than supporting democratic local decision-making processes and institutions.

In an era of continuing land grabbing and struggles over resources, eliding development with security enables the government to gain control over resources and territory 
alongside casting a bid for legitimacy. Too often, unfortunately, this is at the cost of marginalised populations, often overlapping with their being inhabitants in resource-rich areas (Peluso \& Watts 2001). Deconstructing the manner in which access is authorised through practices of governmental development interventions is a telling technique for ascertaining whose interests these interventions favour and which actors bear the brunt of inequity. Analysing the ongoing practices and key struggles is essential for improvement.

There are naturally practices that are easier to access than others as a researcher, and struggles over authority are more evident in some contexts than others. This is because some are better at hiding such practices whilst others are unable to openly contest issues of access. But even based on available evidence, the case of SAP in Saranda reveals a government abdicating its responsibility towards marginalised communities in favour of large-scale mining companies by seeing development as security. While the practices are less animated in Sadar Chaibasa, the outcome suggests indifference rather than an attempt at building a democratic state. Seeing development as security in Jharkhand thus seems to be a policy choice that structures access through top-down authority in ways that depart from the mandate of the Indian Constitution. It is a strategy worth reconsidering and changing.

\section{BIBLIOGRAPHY}

Abrams, Philip (1988) 'Notes on the Difficulty of Studying the State', Journal of Historical Sociology, 1(1), pp. 58-89.

Agamben, Giorgio (2009) What Is an Apparatus? And Other Essays, Stanford: Stanford University Press.

Althusser, Louis (1971) 'Ideology and Ideological State Apparatuses (Notes Towards an Investigation)', in L. Althusser, Lenin and Philosophy and other Essays (B. Brewster, Trans.), London: New Left Books.

Areeparampil, Mathew (1992) 'Forest Andolan in Singhbhum', in S. Narayan (ed.), Jharkhand Movement: Origin and Evolution, New Delhi: Inter-India, pp. 144-18.

Baka, Jennifer (2013) 'The Political Construction of Wasteland: Governmentality, Land Acquisition and Social Inequality in South India', Development and Change, 44(2), pp. 409-28.

Banerjee-Guha, Swapna (2013) 'Accumulation and Dispossession: Contradictions of Growth and Development in Contemporary India', South Asia: Journal of South Asian Studies, 36(2), pp. 165-79.

Basu, Ipshita (2011) 'Security and Development-Are They Two Sides of the Same Coin? Investigating India's Two-Pronged Policy towards Left Wing Extremism, Contemporary South Asia, 19(4), pp. 373-93.

Bedi, Heather P. (2015) 'Judicial Justice for Special Economic Zone Land Resistance', Journal of Contemporary Asia, 45(4), pp. 596-617. 
Chandra, Uday (2014) 'The Maoist Movement in India', Social Movement Studies: Journal of Social, Cultural and Political Protest, 13(3), pp. 414-19.

Corbridge, Stuart; Jewitt, Sarah; Kumar, Sanjay (2004) Jharkhand: Environment, Development, Ethnicity, New Delhi: Oxford University Press.

Corbridge, Stuart; Jewitt, Sarah (1997) 'From Forest Struggles to Forest Citizens? Joint Forest Management in the Unquiet Woods of India's Jharkhand', Environment and Planning A, 29(12), pp. 2145-64.

Cruikshank, Barbara (1999) The Will to Empower: Democratic Citizens and Other Subjects, Ithaca: Cornell University Press.

Dandekar, Ajay; Choudhury, Chitrangada (2009) PESA, Left-Wing Extremism and Governance: Concerns and Challenges in India's Tribal Districts, Anand: Institute of Rural Management, Anand.

ELDF (Environment Law and Development Foundation) (2012) Towards Better Forest Governance in India: A Comprehensive Manual on Forest Rights Act and PESA Jharkhand. New Delhi: ELDF.

Ferguson, James (1990) The Anti-Politics Machine: 'Development', Depoliticization, and Bureaucratic Power in Lesotho, Cambridge: Cambridge University Press.

Foucault, Michel (1980) Power/Knowledge: Selected Interviews and Other Writings 1972-1977, Brighton: Harvester Press.

Foucault, Michel (1972) The Archaeology of Knowledge, London: Tavistock.

Fraser, Nancy (2001) 'Recognition without Ethics?’ Theory, Culture \& Society, 18(2-3), pp. 21-42.

Freudenburg, William R. (2005) 'Privileged Access, Privileged Accounts: Toward a Socially Structured Theory of Resources and Discourses', Social Forces, 84(1), pp. 89-114.

GoJ (Government of Jharkhand) (2006) 'Introduction', in Forest Resources Survey, Chaibasa South, pp. 1-46.

GoJ (2013a) Sadar Chaibasa Forest Division Working Plan 2013-2023, Chaibasa: Jharkhand State Forest Department.

GoJ (2013b) Integrated Wildlife Management Plan for West Singhbhum, Jharkhand, Department of Forest and Environment.

Gupta, A. (2015) ‘Saranda Template for 10 Maoist Hubs’, The Telegraph, 4 March 2015, URL: http:// www.telegraphindia.com/1150305/jsp/frontpage/story_7025.jsp.

JHRM (Jharkhand Human Rights Movement) (2012) Jharkhand Human Rights Movement Letter on the Saranda Action Plan: Factsheet on Situation in Saranda. URL: http://sanhati.com/articles/4595/.

Jewitt, Sarah (2008) 'Political Ecology of Jharkhand Conflicts', Asia Pacific Viewpoint, 49(1), pp. 6882.

Kirpal, Raman (2010) ‘Why You Must Read This Censored Chapter', Tehelka, 7(27), URL: http:// www.tehelka.com/story_main45.asp?filename=Ne100710censoredchapter.asp.

Kumar, Sanjay (2002) 'Does "Participation" in Common Pool Resource Management Help the Poor? A Social Cost-Benefit Analysis of Joint Forest Management in Jharkhand, India', World Development, 30(5), pp. 763-82.

Kumar, Sanjay; Corbridge, Stuart (2002) 'Programmed to Fail? Development Projects and the Politics of Participation', Journal of Development Studies, 39(2), pp. 73-103. 
Lahiri-dutt, Kuntala; Balakrishnan, Radhika; Ahmad, Nesar (2012) 'Land Acquisition and Dispossession Private Coal Companies in Jharkhand', Economic \& Political Weekly, 42(6), pp. 39-45.

Legg, Stephen (2011) 'Assemblage/apparatus: Using Deleuze and Foucault', Area, 43(2), pp. 12833.

Lele, Sharachchandra; Kiro, Vasavi; Roma; Meena, Ramdhanlal (2010) Implementation of Forest Rights Act in Jharkhand: Report of Field Visit, MoEF/MoTA Committee on Forest Rights Act.

Levien, Michael (2013a) 'The Politics of Dispossession: Theorizing India’s “Land Wars”', Politics \& Society, 41, pp. 351-94.

Levien, Michael (2013b) 'Regimes of Dispossession: From Steel Towns to Special Economic Zones', Development and Change, 44(2), pp. 381-407.

Li, Tania M. (2007) 'Practices of Assemblage and Community Forest Management', Economy and Society, 36(2), pp. 263-93.

Lund, Christian (2008) Local Politics and the Dynamics of Property in Africa, Cambridge \& New York: Cambridge University Press.

Lund, Christian (2011) 'Property and Citizenship: Conceptually Connecting Land Rights and Belonging in Africa', Africa Spectrum, 46(3), pp. 71-5.

Mitchell, Timothy (2002) Rule of Experts: Egypt, Technopolitics, Modernity, Berkeley: University of California Press.

MoLJ (Ministry of Law and Justice, Government of India) (2007) The Scheduled Tribes and Other Traditional Forest Dwellers (Recognition of Forest Rights) Act 2006, New Delhi: MoLJ.

MoPR (Ministry of Panchayati Raj, Government of India) (1992) The Constitution (73 ${ }^{\text {rd }}$ Amendment) Act, 1992, New Delhi: MoPR.

MoPR (Ministry of Panchayati Raj, Government of India) (1996) Panchayats (Extension to Scheduled Areas) Act 1996, New Delhi: MoPR.

MoRD (Ministry of Rural Development, Government of India) (2011) Saranda Action Plan, New Delhi: MoRD.

Nightingale, Andrea J.; Ojha, Hemant R. (2013) 'Rethinking Power and Authority: Symbolic Violence and Subjectivity in Nepal's Terai Forests', Development and Change, 44(1), pp. 29-51.

Oskarsson, Patrik (2015) ‘Governing India’s Bauxite Mineral Expansion: Caught between Facilitating Investment and Mediating Social Concerns', The Extractive Industries and Society, 2(3), pp. 426-33.

Oskarsson, Patrik; Nielsen, Kenneth B. (2014) 'Development Deadlock: Aborted Industrialization and Blocked Land Restitution in West Bengal and Andhra Pradesh, India', Development Studies Research. An Open Access Journal, 1(1), pp. 267-78.

Padel, Felix; Das, Samarendra (2010) 'Cultural Genocide and the Rhetoric of Sustainable Mining in East India', Contemporary South Asia, 18(3), pp. 333-41.

Pandit, Arbind P.; Sinha, Vishnu S.; Kumar, Nandjee; Choudhary, Udaykant (2014) 'Assessment of Ground Water Quality of Noamundi, Jharkhand with Special Reference to Iron', Journal of Chemistry and Chemical Sciences, 4(3), pp. 118-24.

Peluso, Nancy L.; Watts, Michael (2001) Violent Environments, Ithaca, NY: Cornell University Press. Prakash, Amit (2011) 'Politics, Development and Identity: Jharkhand, 1991-2009', in D. J. Rycroft; S. Dasgupta (eds.), The Politics of Belonging in India: Becoming Adivasi, pp. 175-89. 
Ramesh, Jairam (2012) 'Give the Saranda Development Plan a chance’, The Hindu, 12 June, URL: http://www.thehindu.com/opinion/op-ed/give-the-saranda-development-plan-a-chance/ article3494009.ece.

Rath, Govinda C. (2006) 'The Struggle for Self-Governance: The Gram Sabha Movement for Implementation of the PESA Act in Jharkhand', Man in India, 86(1-2), pp. 51-63.

Ray, Sarthak (2012). 'What does Intense Mining Mean to Saranda Tribals?', Governance Now, 15 June, URL: http://www.governancenow.com/news/regular-story/what-does-intense-miningmean-saranda-tribals.

Ribot, Jesse C. (2011) Choice, Recognition and the Democracy Effects of Decentralization (Working Paper 5), Visby: Swedish International Centre for Local Democracy.

Ribot, Jesse C.; Peluso, Nancy L. (2003) 'A Theory of Access’, Rural Sociology, 68(2), pp. 153-81. Rose, Nikolas (1999) Powers of Freedom: Reframing Political Thought, Cambridge: Cambridge University Press.

Rycroft, Daniel J.; Dasgupta, Sangeeta (2011) The Politics of Belonging in India: Becoming Adivasi, London \& New York: Routledge.

Scott, James (1999) 'Foreword', in Gilbert M. Joseph \& Daniel Nugent (eds.), Everyday Forms of State Formation: Revolution and the Negotiation of Rule in Modern Mexico, Durham (North Carolina): Duke University Press, pp. xi-xii.

Sen, Asoka K. (2011) Representing Tribe: The Ho of Singhbhum under Colonial Rule, New Delhi: Concept Publishing Company.

Sethi, Aman (2012a) 'Nine Months on, Police Camps Sole Development in Saranda Plan', The Hindu , 6 June, URL: http://www.thehindu.com/news/national/nine-months-on-police-camps-soledevelopment-in-saranda-plan/article3487034.ece.

Sethi, Aman (2012b) 'Aman Sethi Responds', The Hindu, 13 June, URL: http://www.thehindu.com/ opinion/op-ed/aman-sethi-responds/article3494008.ece.

Sethi, Nitin (2015) 'Environment Ministry Tries Another Ploy to Dilute Tribal Rights', Business Standard, 14 March, URL: http://www.business-standard.com/article/current-affairs/ environment-ministry-tries-another-ploy-to-dilute-tribal-rights-115031300772_1.html.

Shah, Alpa (2010) In the Shadows of the State: Indigenous Politics, Environmentalism, and Insurgency in Jharkhand, India, Durham: Duke University Press.

Shah, Alpa (2006) 'Markets of Protection: The "Terrorist" Maoist Movement and the State in Jharkhand, India', Critique of Anthropology, 26(3), pp. 297-314.

Shah Commission, Justice M. B. (2013) First Report on Illegal Mining of Iron and Manganese Ores in the State of Jharkhand (Vol. IV), New Delhi: Ministry of Mines.

Sharan, Ramesh (2005) 'Alienation and Restoration of Tribal Land in Jharkhand: Current Issues and Possible Strategies', Economic \& Political Weekly, 40(41), pp. 4443-46.

Sikor, Thomas; Lund, Christian (2009) 'Access and Property: A Question of Power and Authority', Development and Change, 40(1), pp. 1-22.

Stacey, Paul (2015) 'Political Structure and the Limits of Recognition and Representation in Ghana', Development and Change, 46(1), pp. 25-47.

Sud, Nikita (2014) ‘Governing India’s Land’, World Development, 60, pp. 43-56. 
Sundar, Nandini (2012) 'Insurgency, Counter-Insurgency, and Democracy in Central India', in Roger Jeffrey, Ronojoy Sen \& Pratima Singh (eds.), More than Maoism: Politics, Policies and Insurgencies in South Asia, New Delhi: Manohar, pp. 149-68.

Sundar, Nandini (2009) Legal Grounds: Natural Resources, Identity and the Law in Jharkhand, New Delhi: Oxford University Press.

Sundar, Nandini (2005) '“Custom" and "Democracy” in Jharkhand', Economic \& Political Weekly, 40 (41), pp. 4430-34.

Tillin, Louise (2011) 'Questioning Borders: Social Movements, Political Parties and the Creation of New States in India', Pacific Affairs, 84(1), pp. 67-87.

Vishnoi, Anubhuti (2013) 'Jairam Opposed but Jindals Allowed to Mine in Saranda', The Indian Express, 2 June, URL: http://archive.indianexpress.com/news/jairam-opposed-but-jindalsallowed-to-mine-in-saranda/1123904/.

World Bank (2003) Executive Summary: A New State: Emergence, Features and Challenges, Washington DC: World Bank.

World Bank (2007) Jharkhand: Addressing the Challenges of Inclusive Development, Washington DC: World Bank.

Yeh, Emily T. (2013) Taming Tibet: Landscape Transformation and the Gift of Chinese Development, Ithaca: Cornell University Press.

\section{NOTES}

1. Control by the central government when a state government cannot function constitutionally.

2. See also Rycroft \& Dasgupta (2011).

3. This requires a license and some political and economic reach.

4. Forests are typically controlled by this line ministry rather than the Revenue Department.

5. From national media reports.

6. Interview with West Singhbhum Deputy Commissioner, January 2015.

7. As Sundar (2012: 162) anticipates for a similar case.

8. See Yeh (2013) for an interesting parallel with China's development interventions in Tibet.

9. Interview code 12-06 (anonymised) conducted on 17.02.2013.

10. Interview code 14-04 (anonymised) conducted on 14.02.2013.

11. I established this through semi-structured interviews, structured interviews on scheme functioning, and key informant interviews, including with project contractors who admitted this.

12. Interview code 01-06 (anonymised) conducted on 02.02.2013.

13. Interview code 05-03 (anonymised) conducted on 11.02.2013.

14. Interview code 14-03 (anonymised) conducted on 04.02.2013.

15. For similar, more nuanced accounts elsewhere in Jharkhand, see Kumar \& Corbridge (2002), Shah (2010).

16. These cost about 17 million dollars for 130 kilometres.

17. An average of roughly an article a week about Saranda in the national media during 2011-14.

18. This is reminiscent of what Shah (2010) terms being 'in the shadows of the state'.

19. Name anonymised.

20. See Corbridge et al. (2004) for elaborate treatment.

21. Tenure of lineage (khunt) members who reclaimed land (katti).

22. Many interviewed villagers said these were granted to score political points for politicians. 


\section{ABSTRACTS}

This article examines governmental development interventions and their local-level implications for access to and authority over resources, using a framework of assemblage practices (Li 2007) as an analytical strategy in a mixed-methods study in Jharkhand's West Singhbhum. This insurgency-affected district, populated by the Ho tribe, has India's largest iron deposits. It hosts the Saranda Action Plan (SAP), a controversial intervention that exemplifies how India's government elides development with security in resource-conflict regions. SAP aims to bring security and development to mineral-rich Saranda forest division, but has been widely critiqued for its failure to deliver community-oriented development, while the security agenda paves the way for mining concessions. Meanwhile, neighbouring Sadar Chaibasa division, with comparable development issues but less minerals, is treated indifferently. Based on secondary research in Saranda and empirical work in Sadar Chaibasa's forest villages, this article untangles the practices through which governmental development interventions construct inequitable resource access locally in both extreme and ordinary cases. It argues that seeing development as security enables the mutual constitution of top-down authorisation and inequitable resource access, building an undemocratic local-level state.

\section{INDEX}

Keywords: governmental development interventions, security, Jharkhand, access, authority, assemblage

\section{AUTHOR}

\section{SIDDHARTH SAREEN}

Visiting Researcher, Nordic Institute of Asian Studies 